\title{
The distinction between term and word: a translator and interpreter problem and the role of teaching terminology
}

\author{
Nasiba MULLAJANOVA ${ }^{1}$ \\ Tashkent State University of Economics
}

\begin{tabular}{l} 
ARTICLE INFO \\
\hline Article history: \\
Received August 2021 \\
Received in revised form \\
20 August 2021 \\
Accepted 15 September 2021 \\
Available online \\
11 October 2021 \\
\\
\hline Keywords: \\
discussion, \\
term, \\
terminology, \\
terminography, \\
semantic ambiguity, \\
teaching terminology, \\
complex physiological.
\end{tabular}

ABSTRACT

This article discusses the difference between term and word: the problem of translator and interpreter and the role of teaching terminology. Human Language is a complex physiological activity influencing and influenced by a vast range of systems. Therefore, fixing a word for a specific meaning and attaching a cultural meaning to words becomes challenging. Here a translator and interpreter mentally get confused. (CC BY 4.0) license (https://creativecommons.org/licenses/by/4.0/deed.ru)

\section{Atama va so'z o'rtasidagi farq: tarjimon muammosi va terminologiyani o'rgatish ahamiyati}

\author{
Kalit so'zlar: \\ munozara, \\ atama, \\ terminologiya, \\ terminografiya, \\ semantik noaniqlik, \\ o'qitish terminologiyasi, \\ murakkab fiziologik.
}

\begin{abstract}
ANNOTATSIYA
Ushbu maqolada atama va so'z o'rtasidagi farq muhokama qilinadi: tarjimon va tarjimon muammosi va terminologiyani o'rgatilgan. Inson tili - bu ko'plab tizimlarga ta'sir qiladigan va ta'sir qiladigan murakkab fiziologik faoliyat ekanligi yoritilgan. Shuning uchun so'zni ma'lum ma'noda aniqlash va so'zlarga madaniy ma'no qo'shish qiyin bo'ladi. Bu erda tarjimon va tarjimon aqli chalkashib ketishini oldini olish yo'llari yoritilgan.
\end{abstract}

\footnotetext{
${ }^{1}$ Lecturer, Tashkent State University of Economics, Tashkent, Uzbekistan.

E-mail: nasiba.chust@gmail.com.
} 


\section{Различие между термином и словом: проблема устного и письменного переводчика и роль преподавания терминологии}

\author{
Ключевые слова: \\ дискуссия, \\ термин, \\ терминология, \\ терминография, \\ семантическая \\ неоднозначность, \\ обучающая терминология, \\ комплекс физиологии.
}

\begin{abstract}
АННОТАЦИЯ
В статье обсуждается различие между термином и словом: проблема переводчика и роль преподавания терминологии. Человеческий язык - это сложная физиологическая деятельность, на которую влияет широкий спектр систем. Таким образом, становится непросто закрепить за словом конкретное значение и придать словам культурное значение. Здесь переводчик и устный переводчик мысленно путаются.
\end{abstract}

\section{INTRODUCTION}

The decisions taken by our state in recent years once again confirm the urgency of the large-scale translation of Uzbek literature, which is a mirror of the nation's artistic thinking, into foreign languages.

In particular, the Resolution of the President of the Republic of Uzbekistan dated September 13, 2017 "On a comprehensive program of measures to develop the system of publishing and distribution of book products, increase and promote the culture of reading and reading" and 2018 Ensuring the implementation of the Resolution No. PQ-3652 "On measures to further improve the activities of the Writers' Union of Uzbekistan" dated April 5, 2006, the translation of selected works of world literature into Uzbek and masterpieces of Uzbek literature into foreign languages Our translators have a great responsibility to develop a clear mechanism for the state ordering system. In particular, the resolution states that "... young people should enjoy the creative potential and skills of the older generation, who have great talent and a high position of citizenship; search for young talents, develop and implement innovative methods based on modern scientific achievements to realize their potential; to translate and publish the best examples of world literature in Uzbek, to translate the best examples of our classical and modern literature into foreign languages and to create a system of promotion abroad. Identification of the best examples of our national literature for the translation of works of art into foreign languages ... Training and development of young translators in fiction, development and implementation of measures to improve the professional skills of existing translators tasks separately highlighted.

Such a high level of attention shows that literary translation is becoming a nationwide business in our country. In L.S. Barkhudarov's formula, "Translation is the process of transforming a speech work in one language into a speech work in another language, while maintaining an unchanged content plan. values. "According to V.N. Komissarov", translation is a type of linguistic mediation in which the original text in a foreign language is transmitted to another language by creating a communicative equivalent text in that language. "According to A. Schweitzer", Translation can be defined as follows:

- one-way and two-phase interlingual and intercultural communication, in which a targeted (translation) analysis of the main text is created on the basis of the topic, the secondary text (metatext) replaces the first in another language and the cultural environment; 
A.V. Fedorov points out, "Translation is the accurate and complete expression of a previously spoken language through another language". In the fidelity and completeness of the translation, he sees the difference between the translation itself and the modification, from a retold or abbreviated presentation, to all sorts of so-called "Adaptations".

The concept of "Translation" encompasses a wide variety of activities. Accordingly, attempts to define a concept can lead to different formulas. The broadest of them is as follows: translation is the correct and complete expression of what was previously expressed in another language through one language ... The difficulty of this task is primarily due to the fact that different language systems are not the same, they among which are specific "Gaps", "Inconsistencies", grammar and stylistics in the field of vocabulary.If you look closely at the translation process, then it becomes clear 2 mandatory stages ... First: the translator analyzes and interprets the meaning and form of translation, learns the meaning of words, understands grammatical structures, identifies stylistic features. At this stage, the translator is required to know the original language. Step Two: The interpreter selects the means of expression in the language being translated. Naturally, at this stage, he is required to master all the riches of the "Target language", ours - the Russian language. It is in the second stage that translation becomes a creative process, as it involves the selection of several options.

\section{Terminology vs. "Adaptation"}

To date, the term "Adaptation" has been one of the most controversial issues in translation studies. It was not until the 1970s that the issue was taken seriously. Some scholars have argued that the term "Adaptation" has nothing to do with translation, while others have argued that "Adaptation is a way of translating". For example, the Ukrainian researcher V.V. Demestkaya in her work "Theory of Translation" explains the concept of "Adaptation" as follows:

1. A method of changing the situation described in the text in an appropriate way in order to adapt it to the receptor;

2. Adaptation is usually understood in a variety of ways: simplifying the form and content, as well as shortening the text to make it easier for the reader to understand;

3. Adapt the text for unprepared readers, for example, to "Facilitate" a work of art for a reader who is just beginning to learn a foreign language.

A.V. Fedorov in his famous book "Fundamentals of General Theory of Translation" completely denies the adaptation of all types of translation activities: or regardless of this phenomenon, the following two conditions are common to all these types of activities:

1. The purpose of translation is to acquaint the reader who does not know a foreign language as closely as possible with the text;

2. Translation is the act of expressing a text already written in one language into another by means of complete and precise means. R.K. Minyar-Beloruchev, in support of Fedorov's theory, argues that adaptation and translation are completely incompatible concepts, noting that in translation, the transmission of the message is observed, and in the adaptation, the message is not transmitted, but the general summary of the oral work is described.

In his book Theory and Practice of Translation, J. Retsker completely avoids the term "Adaptation". It is limited to the concept of "Telling". The researcher explains: 
“The translator's job is to convey the original in a complete and accurate way, using other language tools. The work must retain its stylistic and expressive features. In other words, in contrast to "Narration", the translation must not only reveal the essence of the original work, but also preserve the content and emotional state of the work in the same way as it is expressed. This requirement applies not only to the work itself, but also to its components".

\section{Translation culture}

The word "Culture" was first used by the English scholar Edward B. Tayloming in his 1871 book, Primitive Culture. According to Taylom, culture includes knowledge, beliefs, laws, traditions, and various customs adopted by different members of society. Translation is not just the equivalent of a text, it is as difficult and complicated a process as rewriting the original. It's the influence of one culture on another. To understand translation, we need to define the concepts of culture and language, and focus on the relationship between language and culture. Linguist Gary Witherspoon comments on this relationship: "If we look at culture from a linguistic point of view, the word 'culture' was first used by the English scholar Edward B. Tayloming in his 1871 book, Primitive Culture. According to Taylom, culture includes knowledge, beliefs, laws, traditions, and various customs adopted by different members of society. Translation is not just the equivalent of a text, it is as difficult and complicated a process as rewriting the original. It's the influence of one culture on another. To understand translation, we need to define the concepts of culture and language, and focus on the relationship between language and culture. Linguist Gary Witherspoon comments on this relationship: "If we look at culture from a linguistic point of view, we have a one-sided understanding of culture. If we look at language from a cultural point of view, we have a one-sided understanding of language". The process of transferring elements of culture to another language environment through translation is a complex matter. Culture is a complex set of everyday life experiences that includes history, social system, religion, daily customs and traditions. Social relations are also an element of culture. In some cultures, people are accustomed to living in a large family, and this makes it necessary for each family member to be approached on a daily basis. Each person is called by his name. Because living in large families is not so common in Western nations, the English language is a bit weak to describe the word that expresses the appeal. In some cultures, people treat their elders with a certain respect for their uncle. In English, this is not without its difficulties. Some formalities are also very confusing, for example, the word "Thank you" is translated differently depending on the situation (for a gift, for a service, to say thank you for a reason). Clothing, jewelry, and food are also problems with translation. For example, it is useless to translate the taste of food or its properties to someone who has never heard of it. Traditions and customs are also part of the culture. Whether it is a wedding, a mourning, or a festival, the history, significance, and underlying symbolism behind it can be difficult for a translator. Beliefs and feelings change from culture to culture. In some cultures, white means purity, and black means evil. This means that culture does not only include concrete things like cities, organizations, schools, but also abstract things like ideas, customs, family patterns, and languages. In short, culture is a way of life, a way of life in a society.

\section{Use of grammatical transformations in translation}

Grammatical transformations lead to the emergence of different grammatical and lexical forms. In some cases, they were not closely related and did not have a lexicalgrammatical character. The reason for the widespread use of grammatical transformation 
in translation is explained by the fact that a sentence in Russian or Uzbek does not correspond to the grammatical structure of English: the difference in word order in a sentence is the difference in the order of sentences. In translation, one phrase can be replaced by another. It depends on the transformations, in whole or in part. In translation, adjectives, nouns, verbs, and forms can be interchanged. From American life: White schools - schools for white - schools for whites; white churches - churches for white. In translation, adjectives are often changed by forms. This is due to the existence of the epithet (adjective) phenomenon in the work of art and publicism (literature on sociopolitical issues) of grammatical transformation.

In English, the word order is followed by the main parts: possessive and participle, and then the 2nd part. In the academic (higher) grammar of the Russian language, the word order in a sentence is as follows: hoi, predicate, possessive; in English the opposite is accepted. For example: Yesterday's deal was considered in court. Your message should start at the end of the sentence. The word order in Russian sentences may be different. One of the methods of transformation is relocation, in which the number of language elements (units) in the text is changed. In translation, words, phrases, parts of speech, and the following sentences in complex compound sentences often change. Substitution is the most important aspect of grammatical change, and they affect all types of linguistic units.

The substitution of word forms and word groups is as peculiar as the substitution of a verb, which is not formed from English verbs and represents action. In English, the possessive pronouns are often used interchangeably with the second syllables in Russian. It should be noted that when translating from English, it is often important to express the structure of the English language by following the indefinite verb forms. lib remains. The grammatical structure of a language is an important part of the language system. The elements of grammatical structure are: affixes, forms and constructions of variation, syntactic connection, word order in a sentence, and so on. They serve to differentiate lexical meanings according to grammar or form. Explaining such a meaning in the translation process is as important as the general problem of translation equivalents. The grammatical forms of the different languages rarely coincide in expressing the meaning and function of the syllable. Usually there is a partial equivalence here, which is the expression of grammatical meanings in grammatical forms, it seems that the similarity of the two languages differs only in that the meaning of the link is similar, in other respects. If you refer to an English dictionary, it means changing the meaning of the word "Translate" to the meaning or equivalent of a word in one language to another, "or" to the specificity of a word in one language. is described as preserving in another language as well. More precisely, the meaning is greatly expanded when used in the context of an important translation from English into Uzbek. This meaning is almost identical to the word "Interpret", which means to explain a word in another language. The word, which is now used by translators, has all the meanings. At the same time, the general meaning of the term "translation" is as follows. The translation should be able to express most of the original text in as few words as possible and retain the content and essence of the original text. The translator should not add unrelated ideas or words to the text. The task of the line is not to expand or interpret, but to translate while maintaining the effectiveness and spirit of the original text. It is also important to express meaning through word order. Translation is simply the process of translating a text into another language. 


\section{CONCLUSION}

In the light of above points the article can be concluded into the following points:

$>$ Terminology has been recognized as an academic discipline to be taught in academic institution due to its importance in determining the actual meaning comprehending the distinction between a word and a term with specific concept, domain and discipline.

$>$ Terminology, being the science of creating terms and putting them in use, play a key role in the life of a translator and interpreter. It is evident from the above discussion that term is different from a word as term contains a concept in a specific domain.

$>$ Teaching terminology in the department of translation \& Interpretation at BS level is a new academic experience. Department of Translation \& Interpretation, International Islamic University, Islamabad, deserves to claim except China the credit of being the only department feeling the importance of the discipline and putting it inside the syllabus for teaching at BS Level with thirty-five important academic disciplines.

$>$ The teaching of terminology provided the students clear sense of "Word", "Term", "Terminology", "Terminography", "Semantic \& lexical ambiguities", "Their kinds, usages in various field, with similar and different meaning".

\section{REFERENCES}

1. Andre Lefever. Translation/ History/ Culture. Australia. 2001.

2. Bloomfield L. Language, N. Y., 1964.

3. Catford J.C. A linguistic theory of translation. Lnd., Oxford Univ. Press. 1965. 4. Encyclopedia of Britain. London. 2000.

4. Graham I. Difference in Translation. Camel University Press, 1985.

5. Lectric Law Library (2015) http://www.lectlaw.com/def2/u082.htm Mojela, V.M. (2007). Polysemy and Homonymy: Challenges Relating to Lexical Entries in the Sesotho sa Leboa. Lexicos, 17. Retrieved from http://lexikos.journals.ac.za/pub/ article/view/537.

6. Nunberg G. (1995). Transfers of meaning. Journal of Semantics 12(2), 109-132.

7. Nunberg G. and Zaenen A. (1992). Systematic polysemy in lexicology and lexicography. The Proceedings of Euralex II, 387-395.

8. Olga K. and Faina K. (2007). Essays on Lexicon, Lexicography, Terminography in Russian, American and Other Cultures. Cambridge Scholars Publishing.

9. Pearson J. (1998). Term in Context. John Benjamin Publishing. Popp C. (2001). Nomenclatures and computer-aided terminography.

10. In F. Mayer (Ed), Language for special purpose: perspectives for the new millennium (PP. 195-201). Narr, Tubingen.

11. Pustejovsky J. (1995). The Generative Lexicon. Cambridge MA: MIT Press. Sonneveld H. and Loenning K. (1993). Terminology: Application in Interdisciplinary Communication.

12. John Benjamin Publishing. Temmerman, R. (2000). Towards New Ways of Terminology Description. The sociocognitive approach. Amsterdam/ Philadelphia: John Benjamins. Temmerman R., Koen K. and Veerle V. (2005). 